\title{
Prefigurative Politics between Ethical Practice and Absent Promise
}

Uri Gordon

uri.gordon@nottingham.ac.uk

Forthcoming in Political Studies - please contact me for citation information and page numbers

\begin{abstract}
'Prefigurative politics' has become a popular term for social movements' ethos of unity between means and ends, but its conceptual genealogy has escaped attention. This article disentangles two components: an ethical revolutionary practice, chiefly indebted to the anarchist tradition, which fights domination while directly constructing alternatives; and prefiguration as a recursive temporal framing, unknowingly drawn from Christianity, in which a future radiates backwards on its past. Tracing prefiguration from the Church Fathers to politicised re-surfacings in the Diggers and the New Left, I associate it with Koselleck's 'process of reassurance' in a pre-ordained historical path. Contrasted to recursive prefiguration are the generative temporal framings couching defences of means-ends unity in the anarchist tradition. These emphasised the path dependency of revolutionary social transformation and the ethical underpinnings of anti-authoritarian politics. Misplaced recursive terminology, I argue, today conveniently distracts from the generative framing of means-ends unity, as the promise of revolution is replaced by that of environmental and industrial collapse. Instead of prefiguration, I suggest conceiving of means-ends unity in terms of Bloch's 'concrete utopia', and associating it with 'anxious' and 'catastrophic' forms of hope.
\end{abstract}

\section{Keywords}

Prefigurative politics; temporal framing; anarchism; Marxism; utopia

\section{Introduction}

\section{EIMASTE EIKONA AПO TO MEMMON}

(We are an image from the future)

Graffiti, 2008 Greek riots

'Prefigurative politics' is by now a familiar term for the ethos of unity of between means and ends distinguishing contemporary social movements. Yet the temporal framings awakened by this concept continue to lurk in the peripheral vision of activists and scholars alike. Concepts travel accidental paths. 'Left' and 'Right' are obvious examples of how pure contingency has shaped our political vocabulary. A concept often becomes institutionalised, not because of its intrinsic richness or explanatory power, but only because of its emergence or appropriation in a certain context and at a certain time, and the ensuing irreversible process of dissemination and repetition across writers. This is also the case with prefigurative politics. Yet despite having reached social movements through a broken line of transmission, this composite concept's temporal resonance remains literally preserved in its prefix, raising troubling questions for those who employ the term.

Much of the empirically-driven work on prefigurative politics suffices with received definitions (McCowan, 2010; Mason, 2014; Howard and Pratt-Boyden, 2013; Baker, 2016), or uses the concept without much 
explanation at all (Young and Schwartz, 2012; Sancho, 2014). Authors who do problematise the term have, to date, abstracted from its temporal implications, asking instead e.g. what part of social movement activity it is supposed to describe ('an action, practice, movement, moment or development' (Van De Sande 2013, p.23)); whether it may coexist with reformist agendas (Siltanen et al., 2015); or how it is differently expressed in micro- and macro-political contexts (Yates 2015); or focusing on its feminist, queer and spatial dimensions (Evans 2009, Wilkinson 2010, Ince 2012, Springer 2014). Scholarship on temporalities in social movements, for its part, has considered cycles of contention (McAdam and Sewell 2001); the 'liminoid' rhythms of confrontational protest (Krøijer 2010); and 'undomesticated' temporalities (Szerszynski 2002), as well as twenty-eight chapters (in Lawrence and Churn 2012) on memory and modernity, capital and utopia, Negri and Deleuze - but not temporal prefiguration.

The lacuna is serious, since prefigurative terminology burdens the ethos of means-ends unity with a misleading temporal framing. In popular usage, the term unproblematically entangles two different notions of ends: as expressions of intrinsic value ('an end in itself'), and as desired future situations ('an end result'). While the former may be immediately achievable (e.g. though anti-hierarchical organising), the latter's intelligibility depends on a temporal framing that connects past, present and future. This article draws attention to prefiguration as a recursive temporal framing central to Christian theology, which has also played a key role in generating reassurance for religious and political movements. It juxtaposes this to the generative temporal framings accompanying the defence of means-ends unity in the anarchist tradition, which remains crucial to 'path-dependency' arguments against hierarchical organisation. My central argument is that today, misleading prefigurative terminology may work to undermine a generative disposition towards the future, deferring the inconvenient confrontation with both the absent promise of straightforward revolutionary transformation, and the prospects of long-term and uneven ecosystem and industrial collapse.

This article is not, therefore, a concept-history in the classical sense. Following Jane Guyer's (2007) influential discussion of temporal framings as an arena in which individuals and groups seek intelligibility, I attempt to "focus on the still-lingering and newly emergent entailments and dissonances that escape their terms of reference" (p. 410) in the concept of prefigurative politics. In foregrounding past and present temporal imaginaries, and investigating their relationship with ethical revolutionary practice, this article's contribution is located at the intersection of ethnology, conceptual history and tendentious political theory.

The article is divided into three parts. The first opens with background discussion of means-ends unity, then moves to a detailed exposition of the temporal framing of prefiguration, drawing on the work of Erich Auerbach. Tracing prefiguration from the Church Fathers to politicised re-surfacings in the Diggers and the New Left, I associate it with Koselleck's 'process of reassurance' in a pre-ordained historical path. The second part fills a major gap by examining the earliest and most sustained defences of means-ends unity by anarchists, and emphasising their use of generative temporal framings. The third part turns to the significance of activist framings that entirely privilege the present, pointing to the affective crisis this may avoid confronting. In suggesting avenues for a generative framing of means-ends unity, I turn to Bloch's notion of 'concrete utopia' and to recent work on 'anxious' and 'catastrophic' forms of hope.

The discussion draws on eclectic sources, but they belong in three distinct categories. First, major intellectual contributions which form a basis for the running argument (Auerbach, Koselleck, Bloch). Second, activist utterances treated as primary sources for critical analysis (Winstanley, Gorz, Bakunin, Goldman, and current anarchists). Finally, secondary scholarly literature is used as background and evidence. All translations are mine. 


\section{Prefiguration, Recursion and Reassurance}

Unlike the ethos for which it stands, the term 'prefigurative politics' itself did not emerge organically in activist discourse, but was introduced by two social theorists: Carl Boggs, who in 1977 published two articles referring to a prefigurative tradition, model or task, and Wini Breines, who two years later reformulated the term as 'prefigurative politics' in her discussion of the New Left. I will give these works closer attention later on. The concept's popularity today reflects more recent attention to the practices of radical environmental, anti-militarist, anti-racist, international solidarity, feminist, LGBT liberation and animal rights groups. These converged notably through the alter-globalisation protest wave of the 00s, which saw a cross-pollination of action repertoires and networking cultures (Routledge et al. 2007, Juris 2008). Unlike the trade unions, NGOs and political parties who also participated in alter-global protests, radical groups rejected top-down organisation, lobbying, and programmes to seize state power. Instead they have promoted anti-hierarchical and anti-capitalist practices: decentralised organisation in affinity groups and networks; decision-making by consensus; voluntary and non-profit undertakings; lower consumption; and an effort to identify and counteract regimes of domination and discrimination (e.g. patriarchy, racism, homophobia and ableism) in activists' own lives and interactions. It is with these practices - not with any temporal framing - that 'prefigurative politics' is typically associated.

Authors who address prefigurative politics chiefly in ethical terms also abstract from temporal implications, theorising ends in terms of goods and values rather than a potential future state of society. Franks (2014), who conceptualises prefigurative politics as virtuous practice, emphasises the intrinsic rather than instrumental valuation of means (thus identifying them with ends), and rejecting vanguardism as consequentialist. Kuhn (2016) also uses a-temporal ethical language in associating prefigurative politics with 'the belief that the establishment of an egalitarian society enabling free individual development is dependent on political actors implementing the essential values of such a society immediately, in their ways of organizing, living, and fighting'. Finally, Milstein's ethical statement is explicitly dissociated from the future:

We're not putting off the good society until some distant future but attempting to carve out room for it in the here and now, however tentative and contorted... consistency of means and ends implies an ethical approach to politics. How we act now is how we want others to begin to act, too. We try to model a notion of goodness even as we fight for it. (Milstein 2000)

Nevertheless, a temporal sense of prefiguration - at once literal, and peripheral in current usage - does surface in some statements. These directly situate current practices in relation to a possible future, defining the concept as 'the idea that a transformative social movement must necessarily anticipate the ways and means of the hoped-for new society' (Tokar, 2003); as 'a strategy that is an embryonic representation of an anarchist social future' (Carter and Morland 2004, p.79); or in which the 'pursuit of utopian goals is recursively built into the movement's daily operation and organizational style' (Buechler 2000, p.207). These temporal associations introduce terminology that goes well beyond the ethical - anticipation, hope, maturation, recursion, representation, utopia. To begin unpacking this future orientation, I turn to the prefigurative idea as it entered western imaginaries of history and social transformation.

Christian exegesis since Paul the Apostle has approached the Hebrew bible as an Old Testament 'having a shadow of good things to come' (Heb10:1). Stripped of its normative and national character, its Christianised significance lies in its foreshadowing of the Gospel, such that 'Christ appears to us preceded by the shadows and the figures which he himself had cast on Jewish history' (de Lubac 1938/1988, p.174). 
Thus Paul says that Adam was 'a figure [тúroৎ, typos] of him that was to come' (Rom 5:15), and that the trials of the Israelites in the wilderness 'became examples [únol, typoi] for us' (1Cor.10:6. cf. Vulgate: 'in figura facta sunt nostri'). Erich Auerbach, in his seminal essay on the term 'figura' identifies Tertullian (c.160-225CE) as the earliest Church Father to develop the sporadic Pauline references to prefiguration into a systematic exegetical approach, also known as Typology (Auerbach 1944/1984, pp.28-30). Thus, among many other examples, in Adversus Marcionem (3:16) Tertullian treats Moses's naming of Joshua (Num. 13:16) as 'a figure of things to come [figura futurorum fuisse]', linking Joshua to his namesake, Jesus of Nazareth, and Joshua's leadership of the Israelites to Jesus' leadership of the 'second people' - Christians into the 'promised land...of eternal life'.

According to Auerbach, 'from the fourth century on, the usage of the word figura and of the method of interpretation connected with it are fully developed in nearly all the Latin Church writers' (p.34). The earliest usage I could find of the specific term prefigure is in the Latin translation of Against Heresies by Irenaeus (c.380 CE). Here he writes (IV.32) that 'the first testament...exhibited a type [typum] of heavenly things...prefiguring [præfigurans] the images of those things which exist in the Church' (Harvey 1857, v.2 p.255). St. Jerome (c.347-420) centres his 53rd Epistle (to Paulinus, De studi Scripturarum) on how Christ is 'predestined and prefigured [prædestinatus autem, et præfiguratus] in the Law and the Prophets'. Thus Deuteronomy is a 'prefiguration of evangelical law [Evangelicae legis praefiguratio]', and Jonah 'calls the world to repent, his shipwreck prefiguring the Passion of the Lord [passionem Domini præfigurans]'. Many other examples use different terminology, from Joshua's lay of the land 'describing the celestial spiritual kingdom of Jerusalem', to Esther who 'in the figure of the Church [in Ecclesiae typo] liberates her people from danger' (Migne 1845 v.22 540-549).

It was St. Augustine of Hyppo (354-430) who 'developed this idea...profoundly and completely' (Auerbach op.cit., p.43). Auerbach gives many examples, to which we may add Augustine's statements in City of God that Cain, 'founder of the earthly city...signifies the Jews who killed Christ the shepherd of men, which Abel the shepherd of sheep was prefiguring [præfigurabat]' (XV.7; Migne 1845, 41.445); and that 'the kingdom of Saul...was the shadow of a kingdom yet to come' and therefore David passed over the opportunity to slay Saul (1 Sam 24.1-7) 'for the sake of what it was prefiguring [propter illud, quod præfigurabat]' (XVII.6; Migne $1845,41.536-7)$.

Prefiguration, then, is a recursive temporal framing in which events at one time are interpreted as a figure pointing to its fulfilment in later events, with the figure cast in the model of the fulfilment. In the exegetical utterances just reviewed, the interpretation is retrospective - both the figure and its fulfilment (Old and New Testaments) precede it in time. Retrospectively, we could today say that Paul's statements 'prefigured' the fuller accounts of typology in Jerome and Augustine. However, prefiguration can also be invoked prospectively, with current events said to prefigure future ones. This is the sense in which John the Baptist's statement about 'he that comes after me' (Matthew 3:11) announces prefiguration. Equally of importance to the Christian scheme, such prospective prefiguration is carried over from exegesis to eschatology, with each figure-fulfilment dyad pointing to a third, final fulfilment and completion in the Second Coming. In this light, argues Auerbach (58-9),

the history of no epoch even has the practical self-sufficiency which...[in the modern view] resides in the accomplished fact...the event is enacted according to an ideal model which is a prototype situated in the future and thus far only promised...every future model, though incomplete as history, is already fulfilled in God and has existed from all eternity in his providence. 
Given the centrality of this temporal framing to the Christian worldview, it is unsurprising that oppositional movements in medieval and early modern Europe often couched their efforts in millenarian terms (Cohn, 1957). A case in point is Gerrard Winstanley, for whom prefiguration became the cornerstone of a comprehensive revolutionary theology. In his pamphlet The True Levellers Standard Advanced, the Diggers' leader explicitly justifies their direct action strategy - expropriation of the commons and withholding of wage labour - as a millenarian fulfilment of biblical prophecy. Winstanley believed it was possible to immanentise the eschaton by establishing an egalitarian society in the present (Hill 1986). Instead of a literal Second Coming, he expected the final rising of the 'Spirit of Christ, which is the Spirit of universal Community and Freedom' to take place in the persons of those who 'lay the Foundation of making the Earth a Common Treasury' (Winstanley 1649, p.14). Therefore, he declares, 'they that are resolved to work and eat together, making the Earth a Common Treasury, doth joyn hands with Christ, to lift up the Creation from Bondage, and restores all things from the Curse' (p.16). Later on, Winstanley uses his own typology in addressing concerns about repression and hardship (ibid.):

And we are assured, that in the strength of this Spirit that hath manifested himself to us, we shall not be startled, neither at Prison nor Death... For by this work we are assured... that Bondage shall be removed, Tears wiped away, and all poor People by their righteous Labours shall be relieved, and freed from Poverty and Straits; For in this work of Restoration there will be no begger in Israel: For surely, if there was no Begger in literal Israel, there shall be no Begger in Spiritual Israel the Anti-type, much more.

Winstanley's final statement does not, in fact, refer directly to scripture, but to an observation Winstanley himself made frequently in his writings (Knott 2011, pp.87-8). Nevertheless, it functions to describe the Diggers's work as a fulfilment of an Old Testament figure. In the terms defined above, Winstanley's prefiguration is retrospective, albeit in the present perfect tense. The Diggers and their actions are not a figure, but the fulfilment of the 'Spiritual Israel' prefigured in the Bible.

I would like to argue that Winstanley's prefigurative thinking is an example of the 'process of reassurance', identified by Reinhard Koselleck among 'groups of activists who wished to...be part of a history moving under its own momentum, where one only aided this forward motion' (Koselleck 1977/2004, pp.199). Koselleck sees the process of reassurance as 'a means of strengthening the will to hurry the advent of the planned future'. Although he associates it with the later $18 \mathrm{C}$ notion of 'making history', there is little doubt that earlier models of political prognosis which never 'fundamentally transcend[ed] the horizon of a Christian eschatology' (p.197) were carried over into it. Winstanley's assurance that the Diggers' actions are the foretold fulfilment of biblical figures is a case in point. Whether the future is announced as the imperative of a divine or world-historical plan, the framing 'serves... as a relief - one's will becomes the executor of transpersonal events - and as a legitimation which enables one to act in good conscience', as well as 'an ideological amplifier, which reached out to others and caught them up' (p.199).

I would like to point to a resurfacing of this process of reassurance in Andre Gorz's 'The Way Forward' (Gorz, 1968), published in the New Left Review shortly after the French uprising. This article stands out because its use of prefiguration predates Boggs by almost a decade, while strikingly integrating the term into an authoritarian Marxist framework. This provides an opportunity to examine secular, political recursive reasoning in isolation from anarchistic ethical strategy. Indeed, Gorz employs familiar stereotypes of anarchism as 'relying on mass spontaneity, seeing insurrection as the royal road to revolution' and 'the theory of all or nothing according to which the revolution must be a quasi-instantaneous act' (p.48). Arguing 
also against 'the immediate construction of socialism and of communism' (p.51), Gorz calls for a 'Guevarist' strategy, in which the revolutionary vanguard performs an educative role. The vanguard party 'prefigures the proletarian State, and reflects for the working class its capacity to be a ruling class' (p.58). In Gorz's scheme, means do not prefigure ultimate ends, but other means. Rather than prefiguring a 'postrevolutionary society', the party's 'central organs, by their cohesion and capacity for political analysis, will prefigure the central power of the transitional period' (p.61).

Unlike his contemporary Marcuse's isolated comment about the 'ingression of the future into the present' (1969, p.88-89), Gorz's repeated use of prefiguration cannot be dismissed as mere literary flourish. Unlike Winstanley's, his framing is prospective, with a present figure looking forward to its future fulfilment. Yet it relies, no less than theological framings, on a universal point of view bridging past, present and future within an unfolding plan; in this case, the orthodox Marxist revolutionary programme. The role of the vanguard is worked out backwards from the only conceivable (to Gorz) endgame, in which it seizes state power. Only the historico-philosophical grounding of this program, with Marx and Lenin's thick account of class and party, yields a sufficiently determinate image of the future (the workers' state) to form a model for the present. Only the givenness of a revolutionary scenario and its protagonists can lend intelligibility to such symbolic projection from the future. This is not to endorse ambitious claims about millenarian recidivism at the heart of the Marxist project (Rothbard 1972). At issue here is determinacy, not determinism. Revolution may not be guaranteed, but the one path that could lead to it is decided. Even more significantly, prefiguration is used here as an almost-transparent conceit. The educative role Gorz describes would lead the workers' movement to become stronger, fulfil more of its potential, or advance to another stage of development. Yet this 'prefiguration as training' can equally be viewed within a generative temporal framing, which develops forward in time without recursive projection from an imagined future endgame. Yet Gorz wants the party to educate by modelling victory, hurrying on the development of class consciousness. In other words, the prefigurative conceit is openly intended to activate a process of reassurance among the working class.

As we shall see later on, it is the absence of reassurance that prefiguration now obscures. For now, I would like to look more closely at the generative temporal framings which have accompanied the ethos of meansends unity now known as 'prefigurative politics'. These appear earliest and most consistently in the anarchist tradition, which none of the originators of the concept served very well.

\section{Ethical Practice and Generative Temporality}

Carl Boggs published his article 'Marxism, Prefigurative Communism and the Problem of Workers' Control' in the decennial double issue of Radical America, a magazine started in 1967 by Paul Bhule and members of Students for a Democratic Society (SDS), but which 'long outlived its seedbed' to become 'an eclectic left publication, bound to no single strategy and certainly to no organization' (Center for Digital Scholarship, n.d.). The article's primary interest is in council insurgencies in Russia, Italy and Germany between 19171920, and it defines the term 'prefigurative' as 'the embodiment, within the ongoing political practice of a movement, of those forms of social relations, decision-making, culture, and human experience that are the ultimate goal' (1977-8, p.101). Boggs attests (pers. comm. 02.07.2016) that he arrived at the term on his own, inspired at the time by Gramsci and Bookchin, but unaware of its use by the Church Fathers or by Gorz. Hence the broken line of transmission.

Boggs's definition above may be called a formal definition, limited to the very correspondence between ultimate goal and ongoing practice, while remaining silent on their content. Contrast this to his statements 
in his article in Theory and Society the same year, 'Revolutionary Process, Political Strategy and the Dilemma of Power' (Boggs, 1977b). Here, he refers to the prefigurative task as one 'which expresses the ultimate ends of the revolutionary process itself: popular self-emancipation, collective social and authority relations, socialist democracy' (p.359). Here instead is a substantive definition which unlike the formal one is not limited to the mere correspondence between goals and practices, but imbues both with particular valuecontent. A substantive definition is also used by Breines, in her paper first presented at the 1979 annual meetings of the American Sociological Association and revised for publication in Social Problems. Brienes, who credits Boggs, defines prefigurative politics as 'attempt to embody personal and antihierarchical values ...to develop the seeds of liberation and the new society (prior to and in the process of revolution) through notions of participatory democracy grounded in [noncapitalist and communitarian] counter-institutions' (Breines 1980, p.421).

The formal definition leaves prefigurative politics open to association with widely varied practices, from the courts-in-waiting of crown pretenders to parliamentary shadow cabinets. Even the cultural practices of white nationalist groups "allow members to participate in relationships that 'prefigure' Aryan dominance" (Futrell and Simi, 2004, p.16). What bridges the formal and substantive definitions is a specific political context, namely opposition to authoritarian variants of Marxism, whose ends and means do not correspond in this way. On its opponents' account, while authoritarian Marxism does posit as its end-goal a stateless communist society 'without force, without compulsion, without subordination' (Lenin 1918/1992, p.80), it proceeds via top-down structures and the seizure of state power. There is no correspondence between means and ends, and revolutionary organisation and action are approached instrumentally. This critique, and the alternative now identified with 'prefigurative politics', were first worked out not by the New Left, but by anarchists starting a century earlier.

Brienes (1980, p.14) accredits anarchism and radical pacifism as the 'real forerunners' of the New Left, but does not go beyond naming Paul Goodman and Murray Bookchin as influential representatives. In his article for Theory and Society, Boggs dedicates all of one page to the anarchist contribution, dismissing it as having merely 'emerged in response to organized Marxism...flailing away helplessly from the outside', 'trapped in its own spontaneism' and 'preoccupation with small face-to-face "organic" institutions' (Boggs, 1977b, p.382). In Radical America, while acknowledging that the prefigurative tradition 'begins with the nineteenth century anarchists' (1977-8, p.100), he outdoes himself (and Gorz) in alleging that the anarchists 'scorned politics', showed 'contempt for "theory" and "organization" in any form' and were 'basically romantic and utopian', looking 'to an idyllic past rooted in a primitive collectivism' (p.105) - all without a shard of evidence. What is more, having first commended prefigurative strategy for viewing 'statism and authoritarianism as special obstacles to be overturned' (p.103), Boggs seems to recoil from the consequences of his own argument, referring almost immediately to prefigurative structures as 'a nucleus of a future socialist state' (p.104) and praising Councillism for not 'contemptuously dismiss[ing]' the 'contestation for state power' (p.105). While recent writers on prefigurative politics have done more to acknowledge its indebtedness to anarchism, what follows is a closer examination of key utterances on means-ends unity in the anarchist tradition. As we shall now see, these attached their ethos consistently to a temporal framing in which recursive prefiguration does not appear.

The formative conflict between the authoritarian and libertarian factions in the First International, personified in Karl Marx and Mikhail Bakunin, came to a head after the fall of the Paris Commune of 1871 (Eckhardt 2016). When the closed General Council of the International resolved that workers must form their own political parties, anarchists held a counter-conference at Sonvilier (Bernese Jura). They produced a circular which defined the counter-program of the social revolution as 'the emancipation of the workers 
by the workers themselves' and rejected 'any directing authority, even be it elected and consented to by the workers' (Jura Federation, 1871). The Circular closes:

The future society should be nothing else than the universalisation of the organisation that the International has formed for itself. We must therefore strive to make this organisation as close as possible to our ideal. How could one expect an egalitarian and free society to emerge out of an authoritarian organisation! It is impossible. The International, embryo of the future human society, must be, from now on, the faithful image of our principles of liberty and federation, and must reject from within any principle tending toward authority, toward dictatorship.

This argument, with its embryonic metaphor, refers to what today might be called a 'path dependency' between revolutionary practices and results, where 'initial moves in one direction elicit further moves in that same direction' and 'the trajectory of change up to a certain point constrains the trajectory after that point' (Kay 2005, p.553). Choices about organization (top-down or bottom-up) end up determining both the form of the revolution (seizure of state power or abolition of the state) and its end result (modified hierarchical structures or free communism). Note that, although connected to 'principles', the argument from path dependency does not emphasise the intrinsic value of practices, but justifies means-ends correspondence in consequentialist terms. The seizure of state power is not rejected solely on ethical grounds, despite being deemed an effective revolutionary means. Rather, it is rejected as ineffective, since it does not result in a classless society but in dictatorship.

In the same year, Bakunin too insisted that the International should organise the masses 'from the bottom up, beginning with the social life of the masses and their real aspirations' and 'not by forcing the natural life of the masses into the straitjacket of the State'. (1871a, p.258) This led him to praise the Communards' disinterest in seizing state power (1871b, p.268-270):

our friends, the Paris socialists, believed that revolution could neither be made nor brought to its full development except by the spontaneous and continued action of the masses, the groups and the associations of the people...[society] can and should reorganise itself, not from the top down according to an ideal plan dressed up by wise men or scholars nor by decrees promulgated by some dictatorial power or even by a national assembly...[but] from the bottom up, by the free association or federation of workers.

By 'spontaneous' Bakunin does not mean impulsive or improvised, but self-directed and voluntary. Such social reorganisation, carried out directly at the grassroots, is therefore antagonistic to imposed artificial structures, which reproduce the alienation of power. Like the Jura anarchists, in calling for immediate social reorganisation Bakunin is thinking about the long-term effects of present actions and structures, and the affordances locked in once a choice between diverging paths is made. By extending and defending their own bottom-up forms of organisation, revolutionary masses can directly achieve some of their objectives. Instrumentally conceived, such organisation not only avoids the pitfalls of authoritarianism and bureaucracy, but creates a stronger social base for strikes and insurrections.

This emphasis on immediate implementation would later become folded into the central anarchist concept of direct action. This concept extends beyond its current association with disruptive tactics to a principle of action without intermediaries. Through direct action, a group or individual uses their own power to prevent an 
injustice or supply a good, as opposed to appealing to an external agent (Gordon, 2008, pp.34-40). Kropotkin thus called on workers to expropriate productive resources and infrastructures, as 'the first step towards a reorganisation of our production on Socialist principles' (Kropotkin, 1988, p.32-3). While Kropotkin had a mass uprising in mind, more localised examples of direct expropriation include land and factory occupations, urban squatting, and digital piracy. With equal importance, direct action includes immediate social reconstruction to the extent possible. The expansion, deepening, and defence of egalitarian social relations achieves its aims immediately, just as a mass trespass directly stops fracking. In both cases the achievement may be temporary or fragile, but it does not involve intermediaries. There is an evident parallel between this wider sense of direct action, and current movements' preference for 'prefigurative politics' over lobbying, litigation and party politics. At stake in all cases - disruption, expropriation and reconstruction - is the non-alienation of collective power, and a rejection of the politics of representation.

The aftermath of the October revolution vindicated anarchists' warnings about means and ends, occasioning Emma Goldman's landmark statement in her Afterword to My Disillusionment in Russia (1924). Concluding her memoir, Goldman asserts that "No revolution can ever succeed as a factor of liberation unless the means used to further it be identical in spirit and tendency with the purposes to be achieved":
All human experience teaches that methods and means cannot be separated from the ultimate aim. The means employed become, through individual habit and social practice, part and parcel of the final purpose; they influence it, modify it, and presently the aims and means become identical.

This is again a statement of path dependency. Notice, however, the abundance of temporal allusions in these final passages (original emphases):
To-day is the parent of to-morrow. The present casts its shadow far into the future...Revolution that divests itself of ethical values thereby lays the foundation of injustice, deceit, and oppression for the future society. The means used to prepare the future become its cornerstone...the ethical values which the revolution is to establish in the new society must be initiated with the revolutionary activities of the so-called transitional period. Revolution is the mirror of the coming day; it is the child that is to be the Man of To-morrow.

Like the embryonic metaphor in the Sonvilier Circular, Goldman's account of means gelling into ends has the present generating the future. This generative temporal framing is situated in 'normal' forward-looking time, without recursion. Revolutionaries' visions for the future are themselves present-tense mental experiences and discursive exchanges. More importantly, the interpretation of the present is self-contained - dependent on ethical values rather than a promised or imagined prototype. Maturation is not guaranteed (the child 'is to be', not 'will be'). Yet what is already accomplished has the 'practical self-sufficiency' which Auerbach associates with the modern view.

This is shown to be a major conceptual difference, rather than a difference of phrasing and emphasis, when we consider how the experimental nature of lived ethics undercuts recursive reasoning. Rejecting the assured blueprints of utopian socialists and Soviet planners alike, anarchists have tended to privilege repeated, concrete experiences of social struggle in which the tension between aspirations and experience is continuously worked out. Goldman describes revolution as "first and foremost, the transvaluator, the bearer of new values. It is the great teacher of the new ethics, inspiring man with a new concept of life" 
(ibid., original emphases). She employs the Nietzschean term 'transvaluation' (Umwertung) without mentioning the philosopher's name, yet it is clear that she took from Nietzsche an attitude that embraces radical open-endedness in the generation of new social visions and practices (Rossdale, 2015; Miething, 2016). The emergence of values and relationships transcending domination is an uncertain process, playful as well as dangerous.

Mobilisation gives rise to unexpected forms of collective power and solidarity, as well as to renewed scrutiny of systems of domination. This drives a process of self-education, challenging activists to partly undo their own socialisation. As Bookchin (1980) would later put this, 'the very process of building an anarchist movement from below is viewed as the process of consociation, self-activity and selfmanagement that must ultimately yield that revolutionary self that can act upon, change and manage an authentic society'. However, this implies that the ends expressed in practice undergo constant reevaluation. Such an open-ended politics leaves any notion of future 'accomplishment' at least partly indeterminate, and thus too unstable to coherently serve as a source of recursive prefiguration. Such a partial indeterminacy of ends is only intelligible within a generative temporal framing, wherein the future is seen as the product of the affordances and contingencies preceding it.

\section{Absent Promise, Crisis and Hope}

So far we have seen that the temporal framings accompanying anarchist accounts of ethical strategy have been generative rather than prefigurative in the temporal sense, seeking to intervene in shaping the future out of the present. Its experimental nature pulls such a framing away from the process of reassurance, and towards a more modest view of future-oriented designs as the 'product of situationally and chronologically determined insight which goes no further than these limitations' (Koselleck, ibid.). However, if nonhierarchical social relations are to be extended and defended with neither the assurances of historical momentum, nor a full determinacy of ends, what remains of activist dispositions towards the future?

One response - 'perhaps nothing' - marks a recent strand in activist expression which attempts to absorb revolutionary accomplishment entirely into current ethical practices, dissociating from the future altogether. This often accompanies, as with Milstein (ibid.), the anti-Leninist refusal to defer ethical practice until 'after the revolution'. A few illustrative examples:

The revolution exists in every moment of our lives...in the present, not in some mythic possible future. (Monkey, 1999)

it is crucial that we seek change not in the name of some doctrine or grand cause, but on behalf of ourselves, so that we will be able to live more meaningful lives...rather than direct our struggle towards world-historical changes which we will not live to witness. (CrimethInc. 2000)

The revolution is now, and we must let the desires we have about the future manifest themselves in the here and now as best as we can. When we start doing that, we stop fighting for some abstract condition for the future and instead start fighting to see those desires realized in the present... as a flowering of one's selfdetermined existence (Hodgson, 2003) 
Approvingly, Springer theorises such outlooks as a micro-political anarchism, which rejects "end-state politics", prefers "permanent insurrection" to "final revolution", and "abandons any pretext of achieving a completely free and harmonious society in the future and instead focuses on the immediacies of anarchist praxis and a prefigurative politics of direct action in the present" $(2014$, p.264). To be sure, there are limits to how far lived practices can actually go - both due to external limits (that we still live in a capitalist, patriarchal society), and internal ones (that we cannot immediately or completely undo our troubled histories and hierarchical socialisation). Nevertheless, in such expressions the very desire to inhabit social settings which work to undo domination notivates their construction. All these formulations amplify the intrinsic value of anti-hierarchical relations by tying them to personal fulfilment, with individual liberation and social contention each supplying the other's motivation. Recalling the slogan also attributed to Goldman - 'if I can't dance, it's not my revolution' (Shulman 1991), this reading of anarchist practice turns away from a politics of self-sacrifice towards a politics of self-realisation and revolutionary lifestyle (Portwood-Stacer, 2013).

The turn to the present has been criticised as a symptom of activist networks becoming mere cultural scenes, abandoning revolutionary politics for self-seeking pursuits (Bookchin 1995, cf. Davis 2010). Another critique (Olson 2011) has been that the short-term focus on cultural reproduction and confrontational tactics neglects movement-building and class solidarity. My own critique is more basic. I would like to argue that expressions of presentism, in their eagerness to avoid a Leninist disposition towards the future, also conveniently sidestep an anarchistic generative disposition and its consequences. While the statements above dismiss the future as 'distant', 'mythical' or 'abstract', no threat to lived ethical practice is posed by imagining long-term social scenarios, or thinking generations ahead. Instead, I would suggest that presentism covers for a reluctance to confront the absent promise of revolutionary accomplishment, as well as the bleak prospects that become evident once activists approach the future generatively.

Guyer (op.cit.) considers the evacuation of the near future in current hegemonic temporal framings, as neoliberal monetraism defers prosperity to future horizons. She notes the curious similarity between neoliberal and evangelical framings, in which the present is read for signs of promised future fulfilment. For transformative movements, a parallel process has been the evacuation of the future by traditional forms of revolutionary expectation. A century or more ago, anarchists who had experienced the revolutions of th 1848 and 1871 could still expect that 'when the hour of the People's Revolution strikes again' (Bakunin 1866, p.85) it would raise the 'simultaneous revolutionary alliance and action of all the people of the civilized world' (p.96) against reaction. Kropotkin (1886) too was convinced that 'a great revolution is growing up in Europe' which would see 'a rapid modification of outgrown economical and political institutions' and 'a displacement of wealth and political power', over a period 'lasting for several years'. Such expectations did not require an appeal to historical inevitability; they were based on an instinctive understanding of cycles of contention, and an appreciation - too high, in hindsight - of the generative power of mass movements invested in their material and cultural base. Today, however, even such a guarded promise of revolution in advanced capitalist countries seems far fetched. The past century has continued to see democratic and socialist political revolutions, as well as military coups and civil wars, but none have achieved a classless society. The tremendous growth in states' military and surveillance powers, the continuing appeal of nationalism, and insights as to the lack of any keystone centre of power open to definitive attack, have also rendered such optimistic expectations obsolete.

Even more crucially, any generative disposition towards the future must now account for industrial civilisation's transgression of multiple planetary tipping points, as global resource-use continues to grow unabated (Hughes at al., 2013). Hence, expectations of transformation must be projected into a future 
shaped by runaway climate change, energy depletion, ecosystem collapse, inequality, deprivation and conflict (Haraway 2016, Danowski and Viveiros de Castro 2017). My argument is that the absence of revolutionary promise and awareness of converging planetary crises have together cast transformative politics into a crisis. The affective space attached to disposition towards the future, long vacated by reassurance and even expectant optimism, is now filled with anxiety, frustration and guilt. Presentism sidesteps this crisis by avoiding any disposition towards the future altogether. The same denial is served by the continued use of 'prefigurative' terminology. Its literal and surplus meanings, faintly resonating with reassurance, point down the dead end of recursive temporality. This is a confusing distraction from the urgent task of re-working generative framings to account for protracted, uneven and irreversible collapse.

If the term 'prefigurative politics' can be safely abandoned, what could replace it? A focus on substance, as in 'anti-hierarchical politics', could certainly go quite far. But can means-ends unity and ethical practice be framed even more productively, in a way that (a) suggests generative, rather than recursive temporality and (b) may encourage affective dispositions other than reassurance, which can nevertheless sustain the confrontation with converging crises? In closing, I would like to offer preliminary thoughts on one possible avenue for addressing this question, drawing on Ernst Bloch's concept of 'concrete utopia'.

In his project to reinstate utopianism in Marxist thinking, Bloch looks beyond literary descriptions of model societies to the 'positive utopian function' of more concrete imaginings which 'extend, in an anticipating way, existing material into the future possibilities of being different and better' (Bloch 1995, p.144). The anchoring in present reality separates this from what Bloch calls 'abstract utopianism', which ranges from social blueprints to personal daydreams (Levitas 1989). This is because concrete utopianism 'does not play around and get lost in an Empty-Possible, but psychologically anticipates a Real-Possible'. Theological prefiguration and its lingering resonances clearly belong in the abstract category. In distinction, Bloch's 'not-yet' faces all possible future states of the real world, while drawing hope from the tendencies and latencies of a self-transforming present. As a result, concrete-utopian impulses correspond not to fantasy, but to hope and action.

\footnotetext{
Utopian function as the comprehended activity of the expectant emotion, of the hope-premonition, maintains the alliance with all that is still morning like in the world. Utopian function understands what is exploding, because it is this itself in a very condensed way: its Ratio is the unweakened Ratio of a militant optimism. Therefore: the act-content of hope is, as a consciously illuminated, knowingly elucidated content, the positive utopian function.
}

Bloch's temporal framing of concrete utopianism is generative, seeing it as a thought-behaviour which 'contains within it the forward surge of an achievement which can be anticipated' (148). To be sure, Bloch maintains fealty to the Marxist tradition and some attachment to its determinacy can be felt in his account of concrete utopia. True to colours, he puts his erudite gloss on the obligatory dismissal of anarchism, personified in Stirner and Proudhon's 'petit-bourgeois' sensibilities and in Bakunin's 'complete monomania of hatred of authority' (p.573). Alongside its individualism, Bloch asserts, the anarchist image of freedom is 'a bit of future in the future, for which no present prerequisites exist anywhere at all', while 'certain anarchic themes' are 'already to be found in Marxism, sensibly enough not as present postulates but as prophecies and conclusions' (p.574). Here Bloch does himself a true disservice by failing to link his concrete utopia to what Boggs would later call the 'prefigurative tradition' of anarchism and councillism. Even more than the mental act-content of hope, it is the construction of living alternatives that can give concrete 
expression to the positive utopian function. With Marxist prejudices at arms length, a 'politics of concrete utopia' might indeed replace 'prefigurative politics' as a colourful descriptor for means-ends unity.

While the ide Concrete utopia successfully binds ethical practice to generative temporal framings, Bloch's attached principle of hope, drawn from the not-yet, requires further modification. What becomes of this principle, once anticipation addresses itself not only to the fruition of concrete-utopian efforts, but also to the inevitable consequences of industrial and neoliberal over-reach? Though significant conceptual work remains to be done here, a promising start may be found in the ideas of 'anxious' and 'catastrophic' hope. In her recent ethnography among practical sustainability activists in Turkey, Bürge Abiral (2015) identifies these forms of hope in her respondents' dispositions towards the future. Unsurprisingly, activists promoting community sustainability, bioremediation, energy transition and Permaculture system design are among the most attuned to prognoses of collapse. Abirail associates the idea of 'anxious hope' with the grain of anxiety always attending the 'belief that small actions matter...that it is not too late to act' (p.93).

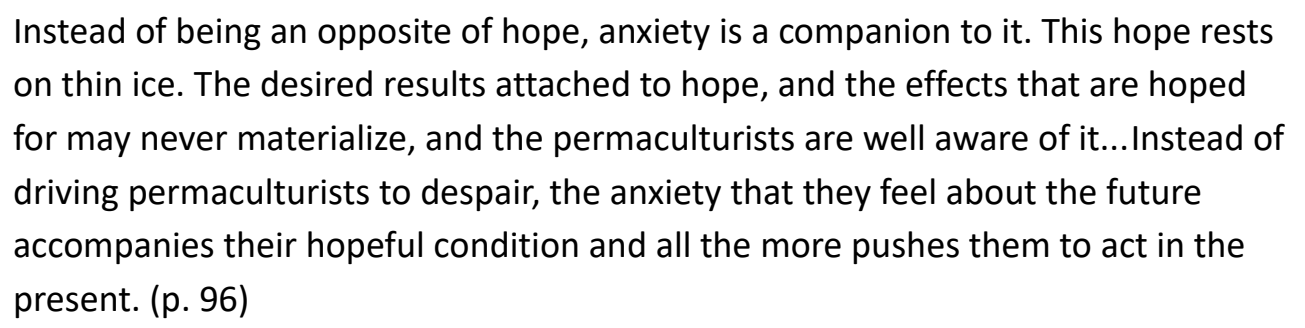

Coexisting with anxious hope is catastrophic hope, an affect which 'combines a catastrophic vision of the future with the conviction that good things will continue to happen despite and because of approaching disasters' (p.97). Catastrophic hope serves as a fallback, providing succour even as it attends to worst case scenarios short of extinction. Such hope can look forward to the adoption of radical alternatives out of the urgency and necessity of a decaying world. From this there can also emerge a reading of catastrophe as a harbinger of revolutionary openings in the future. This form of hope is reminiscent of Lear's concept of 'radical hope' (2009), used to describe the choice to sustain ethics and dignity even through the passage of a way of life. Meditating on the survival of the Native American Crow people, Lear contrasts radical hope to mere optimism, linking it to a virtue ethic centred on courage and imagination. Taken together, anxious and catastrophic forms of hope suggest promising alternatives to the temptations of reassurance, prefiguration and denial.

\section{Conclusion}

In exposing the genealogy of prefiguration, this article has sought to wrest lived ethical practice from the ghostly hand of recursive temporality. To theorise such practice as concrete utopia more adequately captures its generative framing in the anarchist tradition, and eschews the confusing theological and historico-philosophical resonances attached to prefiguration. The approach I have offered seeks confrontation with a toxic future despite the absence of revolutionary promise, drawing on anxious and catastrophic hope to embolden this long-suppressed engagement. More broadly, this article has attempted to show how one may discuss somewhat rarefied theoretical issues without losing touch with activist expression and concerns.

In terms of further research, the reopening of generative temporal framings to the future may support efforts to theorise pathways to radical transformation through the process of collapse. Shedding both 
presentism and the last vestiges of reassurance, such a discussion would bind generative temporal framings to a sober appreciation of the affordances and tendencies of infrastructures and socio-technical systems (Brucato, 2013; see also Ringel 2012; Firth and Robinson, 2014; Groves, 2016). Yet this discussion requires far wider participation. Taking the ethnography of revolutionary futures to diverse movements practising their ends, such research may bring concrete experience and shared ethical commitments to bear on transformative political theory. Facing forward, we only have one another to rely on.

\section{Acknowledgements}

For their helpful comments I thank the four anonymous reviewers as well as Benjamin Franks and Francis Dupuis-Déri.

\section{References}

All links verified 19.04.2017

Abiral, B (2015) 'Catastrophic Futures, Anxious Presents: Lifestyle activism and hope in the Permaculture movement in Turkey'. Masters dissertation, Sabancı University

Auerbach, E. (1944/1984) 'Figura', in Scenes from the Drama of European Literature. Manchester University Press.

Baker, M. (2016) 'The Prefigurative Politics of Translation in Place-based Movements of protest', The Translator, 22(1), pp.1-21

Bakunin, M. (1866), 'Revolutionary Catechism'. in Bakunin on Anarchism, ed. S. Dogloff. New York: Knopf. bit.ly/2oziXdd

Bakunin, M. (1871a), 'The Program of the Alliance', in Dogloff. bit.ly/2oph5rs

Bakunin, M. (1871b), 'The Paris Commune and the Idea of the State', in Dogloff . bit.ly/1X61E2J

Bloch, E. (1959/1995) The Principle of Hope (vol. 3), trans. N. Plaice, S. Plaice and P. Knight. Cambridge, MA: MIT Press

Boggs, C. (1977a) 'Marxism, Prefigurative Communism and the Problem of Workers' Control', Radical America 11(6)/12(1), pp.99-122.

Boggs, C. (1977b) 'Revolutionary Process, Political Strategy and the Dilemma of Power', Theory and Society 4(3), pp.359-93

Bookchin, M. (1980) 'Anarchism Past and Present', Comment 1.6. bit.ly/2poU60p

Bookchin, M. (1995) Social Anarchism and Lifestyle Anarchism: An unbridgeable chasm. Oakland: AK Press 
Breines, W. (1980) 'Community and organization: The New Left and Michels' "Iron Law"', Social Problems 27(4), pp.419-429

Breines, W. (1982) Community and Organization in the New Left. New York: Praeger

Brucato, B. (2013) 'Toward a Peak Everything Postanarchism and a Technology Evaluation Schema for Communities in Crisis'. Anarchist Studies 21(1), pp.28-51

Buechler, S. M. (2000) Social Movements in Advanced Capitalism. Oxford University Press.

Carter, J. and D. Morland (2004) 'Anti-capitalism: Are we all anarchists now?' in Anti-capitalist Britain, Gretton: New Clarion Press

Center for Digital Scholarship (n.d.) Radical America - 1967-1999 (online archive). bit.ly/1sAXvqQ

Cohn, N. (1957) The Pursuit of the Millennium. London: Granada

CrimethInc. (2000) 'Alive in the Land of the dead'. In Days of War, Nights of Love: CrimethInc. for beginners. Olympia, WA: CrimethInc. bit.ly/2pwUEBg

Danowski, D. and E. Viveiros de Castro (2017). The Ends of the World. Cambridge: Polity.

Davis, L. (2010) 'Social anarchism or lifestyle anarchism: an unhelpful dichotomy'. Anarchist Studies 18(1), pp.62-

De Lubac, H. (1938/1988) Catholicism: Christ and the common destiny of man. San Francisco: Ignatius Press Eckhardt, W. (2016) The First Socialist Schism. Oakland: PM Press.

Evans, S. (2009) 'Sons, daughters, and patriarchy: Gender and the 1968 generation'. The American Historical Review 114(2), pp.331-347.

Firth, R. and A. Robinson (2014) 'For the Past Yet to Come: Utopian conceptions of time and becoming'. Time \& Society, 23(3), pp.380-401.

Franks, B. (2014) 'Anti-Fascism and the Ethics of Prefiguration'. Affinities 8(1).

Futrell, R. and P. Simi (2004). 'Free Spaces, Collective Identity, and the Persistence of US White Power Activism', Social Problems 51(1), pp.16-42

Goldman, E. (1925) Afterword to My Disillusionment in Russia. Garden City, NY: Doubleday. bit.ly/1qvPiSP Gordon, U. (2008) Anarchy Alive! Anti-authoritarian politics from practice to theory. London: Pluto Gorz, A. (1968) 'The way forward', New Left Review 1/52, pp.47-66. bit.ly/2nh9sk1 
Groves, C. (2016) Emptying the future: on the environmental politics of anticipation. Futures 88. bit.ly/2nww1Dw

Guyer J. (2007) 'Prophecy and the near future: thoughts on macroeconomic, evangelical, an punctuated time'. American Ethnologist 34(3): 409-421

Haraway, D. (2016) 'Tentacular Thinking: Anthropocene, Capitalocene Chthulucene'. e-flux 75. bit.ly/2oLmB5y

Harvey, W. W., ed. (1857) Sancti Irenaei episcopi lugdunensis libros quinque adversus haereses. Cambridge: Typis Academicis. bit.ly/1ONDTsY

Hill, C. (1986) 'The religion of Gerrard Winstanley', in Collected Essays (vol.2). Brighton: Harvester

Hodgson, T. (2003) 'Towards Anarchy: The Revolution is Now' (blog post). bit.ly/29wW1t9

Howard, N., and K. Pratt-Boyden (2013) 'Occupy London as pre-figurative political action', Development in Practice 23(5-6), pp.729-41.

Hughes, T. et al. (2013) 'Multiscale regime shifts and planetary boundaries'. Trends in Ecology \& Evolution 28(7), pp.389-395.

Ince, A. (2012) In the shell of the old: Anarchist geographies of territorialisation. Antipode 44.5, pp.1645-66 Jura Federation (1871), 'La Circulaire de Sonvilier', in J. Guillaume (1905) L'Internationale: Documents et Souvenirs, 1864-1878. Paris: Société Nouvelle. bit.ly/2oppf3h

Juris, J. (2008) Networking Futures. Durham, NC: Duke University Press.

Kay, A. (2005) 'A Critique of the Use of Path Dependency in Policy Studies'. Public Administration 83(3), pp.553-571

Knott, J. R. (2011) The Sword of the Spirit. Eugene, OR: Wipf \& Stock

Krøijer, S. (2010) 'Figurations of the Future: On the Form and Temporality of Protests among Left Radical Activists in Europe'. Social Analysis 54:3, pp.139-152

Kropotkin, P. (1988) Act for yourselves. Articles from Freedom, 1886-1907, eds. N. Walter and H. Becker. London: Freedom

Kropotkin, P. (1886) 'What Revolution Means', Freedom 1(2). bit.ly/29kdEqM

Kuhn, G. (2016) 'Revolution Is More Than a Word: 23 Theses on Anarchism' (blog post), bit.ly/23Y6DB4

Koselleck, R. (1977/2004) 'On the Disposability of History', in Futures Past, trans. K. Tribe. New York: Columbia University Press, pp.192-204 
Lawrence, C. and Churn, N., eds. (2012) Movements in Time: Revolution, social justice and times of change. Newcastle: Cambridge Scholars

Lear, J. (2009) Radical Hope: Ethics in the face of culural devastation. Harvard University Press

Lenin, V. I. (1917) The State and Revolution. London: Penguin

Levitas, R. (1990) 'Ernst Bloch on Abstract and Concrete Utopia'. Utopian Studies 1:2, pp. 13-26

Maeckelbergh, M. (2011) 'Doing is Believing: Prefiguration as strategic practice in the alterglobalization movement', Social Movement Studies 10(1), pp.1-20

Marcuse H. (1969) An Essay on Liberation. Boston: Beacon Press. bit.ly/2aqe1mt

Mason, K. (2014) 'Becoming Citizen Green: Prefigurative politics, autonomous geographies, and hoping against hope', Environmental Politics 23(1), pp.140-158

McAdam, D. and W. H. Sewell (2001) 'It's about time: Temporality in the study of social movements and revolutions' in Silence and voice in the study of contentious politics. Cambridge University Press, pp.89-125.

McCowan, T. (2010) 'School democratization in prefigurative form: two Brazilian experiences', Education, Citizenship and Social Justice 5(1), pp.21-41

Miething, D. (2016) Anarchistische Deutungen der Philosophie Friedrich Nietzsches. Baden-Baden: Nomos Migne, J.-P. (1845) Patrologia Latina. Paris.

Milstein, C. (2000), 'Reclaim the cities: from protest to popular power'. Perspectives on Anarchist Theory 4(2); bit.ly/200IXhS

Monkey (1999) 'Forest Life' (blog post). bit.ly/2oUPgEb

Portwood-Stacer, L. (2013) Lifestyle politics and radical activism. New York: Bloomsbury.

Rethmann, P. (2015) 'Internationalism, temporality and hope: a view from Eastern Europe and the Left', Social Anthropology 23(4), pp.480-491.

Ringel, F. (2012) 'Towards anarchist futures? Creative presentism, vanguard practices and anthropological hopes'. Critique of Anthropology 32(2) pp.173-188

Rossdale, C. (2015). 'Dancing ourselves to death: The subject of Emma Goldman's Nietzschean anarchism', Globalizations 12(1), pp.116-133.

Rousselle, D. and S. Evren (2011), eds. Post-anarchism: a reader. London: Pluto Press

Rothbard, M. (1990) 'Karl Marx: Communist as religious eschatologist', The Review of Austrian Economics 4, pp.123-179. 
Routledge, P., A. Cumbers and C. Nativel (2007). 'Grassrooting network imaginaries: Relationality, power, and mutual solidarity in global justice networks', Environment and Planning A 39(11), pp.2575-2592.

Sancho, G. R. (2014) 'Networks, insurgencies, and prefigurative politics: A cycle of global indignation', Convergence: The International Journal of Research into New Media Technologies 20(4), pp.387-401

Shulman, A. K. (1991) 'Women of the PEN: Dances with feminists', Women's Review of Books 9(3)., p.13

Siltanen, J., F. Klodawsky, and C. Andrew (2015) "'This is how I want to live my life": An experiment in prefigurative feminist organizing for a more equitable and inclusive city', Antipode 47(1), pp.260-79

Springer, S. (2014) Why a radical geography must be anarchist. Dialogues in Human Geography 4(3)

Szerszynski, B. (2002) Wild times and domesticated times: the temporalities of environmental lifestyles and politics. Landscape and Urban Planning 61, pp.181-191

Tokar, B. (2003) 'Review of Joel Kovel, The Enemy of Nature', Tikkun 18.1, pp.77-8

Van de Sande, M. (2013) 'The Prefigurative Politics of Tahrir Square - An Alternative Perspective on the 2011 Revolutions', Res Publica 19(3), pp.223-239

Wilkinson, E. (2010) What's queer about non-monogamy now? In Understanding Non-Monogamies, eds. M. Barker and D. Langrdridge. London: Routledge

Winstanley, G. (1649/2009) 'The True Levellers Standard Advanced', in Complete Works (vol.2), eds. T. Corns, A. Hughes and D. Loewenstein. Oxford University Press., pp.1-30 bit.ly/1XG2dNc

Yates, L. (2015) 'Rethinking prefiguration: Alternatives, micropolitics and goals in social movements', Social Movement Studies 14(1), pp.1-21

Young, K. and M. Schwartz (2012) 'Can prefigurative politics prevail? The implications for movement strategies in John Holloway's “Crack Capitalism”', Journal of Classical Sociology 12(2), pp.220-39 